\title{
Prevalence and Genetic Diversity of Grapevine Virus D in Tunisia
}

Ilhem Selmi, Laboratoire de Protection des Végétaux LR16INRAT04, Institut National de la Recherche Agronomique de Tunisie, Université de Carthage, Rue Hedi Karray, 1004 ElMenzah, Tunis, Tunisia, Toufic Elbeaino, Istituto Agronomico Mediterraneo di Bari, Via Ceglie 9, 70100 Valenzano, Bari, Italy, Lehad Arezki, Laboratoire de Phytopathologie et Biologie Moléculaire, Ecole Nationale Supérieure d'Agronomie, Rue Hacen Badi, Belfort, El Harrach, 16000 Alger, Algeria, Manel El Air, Laboratoire de Protection des Végétaux LR16INRAT04, Institut National de la Recherche Agronomique de Tunisie, Université de Carthage, Rue Hedi Karray, 1004 ElMenzah, Tunis, Tunisia, Michele Digiaro, Istituto Agronomico Mediterraneo di Bari, Via Ceglie 9, 70100 Valenzano, Bari, Italy, and Naima Mahfoudhi, Laboratoire de Protection des Végétaux LR16INRAT04, Institut National de la Recherche Agronomique de Tunisie, Université de Carthage, Rue Hedi Karray, 1004 ElMenzah, Tunis, Tunisia https://doi.org/10.52543/tipp.16.2.1

(Tunisia / Italy / Algeria)

\begin{abstract}
Selmi, I., Elbeaino, T., Arezki, L., El Air, M., Digiaro, M., and Mahfoudhi, N. 2021. Prevalence and genetic diversity of grapevine virus D in Tunisia. Tunisian Journal of Plant Protection 16 (2): 19-27.

The prevalence and the genetic diversity of grapevine virus D (GVD) isolates from rootstocks, wine and table grape varieties grown in Tunisia were studied. RT-PCR assays performed on the coat protein gene (CP) showed the presence of GVD in $31.5 \%$ of the 403 samples tested. The highest rate of infection was found in table grapes (56.5\%), followed by autochthonous table grapes $(24.1 \%)$, wine grapes $(20.8 \%)$ and rootstocks (12.5\%). Sequences and phylogenetic analyses of the partial CP genes of 14 GVD isolates showed nucleotide identities that ranged from $84 \%$ to $99 \%$. The Tunisian GVD-isolates segregated in 3 phylogenetic groups together with international isolates reported in GenBank. The present study extends our knowledge of the presence of GVD in Tunisian vines and on its genetic diversity, which is useful for developing broad-spectrum molecular diagnostics (RT-PCR) capable of detecting the different isolates infecting vines.
\end{abstract}

Keywords: Grapevine, phylogenetic analysis, RT-PCR, sequences, vitiviruses

Rugose wood (RW) represents one of the most important grafttransmissible diseases affecting Vitis species worldwide (Martelli and Boudon-

Corresponding author: Naima Mahfoudhi

Email: nmahfoudhi@yahoo.fr

Accepted for publication 25 December 2021

Tunisian Journal of Plant Protection
Padieu 2006). Four disorders distinguishable by grafting onto woody indicators plants are associated with this complex disease: stem pitting on Vitis rupestris, stem grooving on Kober $5 \mathrm{BB}$, corky bark and stem grooving on LN33 (Martelli 2014). Some of these syndromes are associated with vitiviruses of the family Betaflexiviridae. Grapevine virus A (GVA) is associated with stem grooving 
on Kober 5BB (Digiaro et al. 1994; Garau et al. 1994; Chevalier et al. 1995), grapevine virus $B(G V B)$ is recognized as the causal agent of corky bark (Bonavia et al. 1996) and grapevine virus $\mathrm{D}$ (GVD) is associated to the growth reduction of Freedom rootstock (AbouGhanem et al. 1997). Additionally, these vitiviruses are frequently detected in coinfection with grapevine leafroll viruses, resulting in synergetic interactions that can lead to lethal effects in several scion and rootstocks combinations (Rowhani et al. 2018). In recent years, several new vitiviruses have been isolated from grapevine (GVE, GVF, GVG, GVH, GVI, GVJ, GVL and GVM) but their potential pathogenic role in RW disease is still unknown (Nakaune et al. 2008; Al Rwahnih et al. 2012; Blouin et al. 2018a and 2018b; Candresse et al. 2018; Diaz-Lara et al. 2018; Alabi et al. 2019; Debat et al. 2019).

GVD was detected for the first time in south Italy in vines with corky rugose wood symptoms (AbouGhanemet al. 1997). The virus is serologically distantly related to GVA and GVB (Choueiri et al. 1997), but it closely resembles GVA in biological behaviour, particle size and morphology, cytopathology, dsRNA pattern, size of RNA and organization of the 3 ' terminal genomic region. Virions are filamentous particles of about $825 \times 12 \mathrm{~nm}$. The presence of GVD was assessed in Tunisian vineyards in a previous study (Mahfoudhi et al. 2014), but no information was provided about the genetic diversity of its isolates. Therefore, a new investigation has been carried out to determine the genetic population structure of GVD isolates in Tunisia.

\section{MATERIALS AND METHODS Field surveys and sample collection.}

Field surveys were carried out in the main Tunisian grapevine growing areas to assess the GVD occurrence in the vineyards. Mature canes were collected from a total of 403 vine samples, including 141 vines of autochthonous varieties maintained in a germplasm collection plot established at INRAT (Tunis), 115 samples of wine and 115 of table grape varieties from commercial vineyards, and 32 rootstocks from mother tree plots. The number of samples collected was relative to the importance, type and origin of cultivars in Tunisia. Mature canes were randomly collected in winter and stored at $4^{\circ} \mathrm{C}$, until laboratory testing.

\section{Total nucleic acids extraction.}

Total nucleic acids (TNA) were extracted according to Foissac et al. (2001). Two hundred $\mathrm{mg}$ of phloem tissues (cortical scrapings) from each sample were ground in $1 \mathrm{ml}$ of extraction buffer $(4 \mathrm{M}$ guanidine thiocyanate, $0.2 \mathrm{M}$ Sodium acetate $\mathrm{pH}$ 5.2, $25 \mathrm{mM}$ EDTA, $1.0 \mathrm{M}$ potassium acetate $\mathrm{pH} 5.0$ and $2.5 \% \mathrm{w} / \mathrm{v}$ PVP-40) and mixed with $2 \%$ sodium metabisulfite as antioxidant. The mixture was transferred into an Eppendorf tube containing $100 \mu \mathrm{l} \quad \mathrm{N}$-Lauroylsarcosine sodium salt (NLS $10 \%$ ), incubated at $70^{\circ} \mathrm{C}$ for $10 \mathrm{~min}$, and then placed on ice for 5 min. After centrifugation at $10,000 \mathrm{~g}$ for $10 \mathrm{~min}, 300 \mu \mathrm{l}$ of supernatant were transferred to an Eppendorf tube to which $150 \mu \mathrm{l}$ absolute ethanol, $300 \mu \mathrm{l}$ sodium iodide $(6 \mathrm{M})$ and $50 \mu \mathrm{l}$ of silicon dioxide $\left(\mathrm{SiO}_{2}\right)$ were added. The mixture was stirred for $30 \mathrm{~min}$ at room temperature and then centrifuged at 5,000 $\mathrm{g}$ for $1 \mathrm{~min}$. After washing with $500 \mu \mathrm{l}$ of washing buffer (50\% STE 1X, 50\% absolute ethanol), the pellet was re-suspended in $120 \mu \mathrm{l}$ of sterile distilled water, incubated for $3 \mathrm{~min}$ at 70 ${ }^{\circ} \mathrm{C}$ and then centrifuged at $10,000 \mathrm{~g}$ for 3 $\min$. The supernatant containing the total 
nucleic acids was transferred to a new Eppendorf tube and stored at $-20^{\circ} \mathrm{C}$.

Reverse transcription and Polymerase chain reaction ( $R T-P C R)$.

Five hundred ng of TNAs were mixed with $0.5 \mu \mathrm{g}$ random primers and 1.5 $\mu \mathrm{l}$ of sterile water and denatured at $95^{\circ} \mathrm{C}$ for $5 \mathrm{~min}$. Reverse transcription was performed for $1 \mathrm{~h}$ at $39^{\circ} \mathrm{C}$ using 200 units of Moloney Murine Leukemia Virus (Invitrogen Corporation, USA), $4 \mu \mathrm{l}$ buffer (5x First-strand Fs), $2 \mu 1$ DTT (0.1 M) and $0.5 \mu \mathrm{ldNTPs}(10 \mathrm{mM})$ and adjusted to a final volume of $20 \mu \mathrm{l}$ with sterile distilled water. A volume of $2.5 \mu \mathrm{l}$ of the synthetized cDNA was submitted to PCR amplification using a mixture containing $2.5 \mu \mathrm{l} 10 \mathrm{X}$ Taq polymerase buffer, $1 \mu \mathrm{l}$ $\mathrm{MgCl}_{2}$ (50 mM), $1 \mu \mathrm{l}$ dNTPs (10 mM), 0.5 $\mu \mathrm{l}$ of each primer $(20 \mu \mathrm{M})$ [GVD-CP7V (5'-CTTAGGACGCTCTTCGGGTACA3') and GVD-CP471C (5'CTGCTCTCCAACCGACGACT-3')]

(AbouGhanem et al. 1997) and $0.25 \mu \mathrm{l} \mathrm{Taq}$ polymerase $(5 \mathrm{u} / \mu \mathrm{l}) \quad$ (Invitrogen Corporation, CA, USA), and adjusted to a final volume of $25 \mu \mathrm{l}$ with sterile distilled water. PCR reactions consisted of one cycle at $94^{\circ} \mathrm{C}$ for $5 \mathrm{~min}$, followed by 35 cycles of denaturation at $94^{\circ} \mathrm{C}$ for $35 \mathrm{sec}$, annealing at $54^{\circ} \mathrm{C}$ for $45 \mathrm{sec}$ and elongation at $72^{\circ} \mathrm{C}$ for $1 \mathrm{~min}$, and a final extension step at $72^{\circ} \mathrm{C}$ for $7 \mathrm{~min}$. The PCR products were analyzed by electrophoresis in $1.2 \%$ agarose gel in $1 \mathrm{X}$ TBE buffer and visualized under UV light after staining with ethidium bromide.

\section{Sequencing and sequence analysis.}

Fourteen Tunisian GVD isolates from the major cultivated table and wine grape cultivars as well as from autochthonous grapevines from different regions were chosen for the genetic diversity study of this virus. RT-PCR amplicons of all selected isolates were ligated into Strataclone ${ }^{\mathrm{TM}}$ PCR cloning vector PSCA (Stratagene, California, USA), sub-cloned into Escherichia coli DH5 $\alpha$ cells and sequenced.

Sequences of Tunisian GVDisolates obtained from this study were compared to those reported in GenBank. The phylogenetic tree was constructed using the Neighbour-joining (NJ) method (with 1000 bootstrap replicates) under MEGA7 software (Kumar et al. 2016), and the inter- and intra-group genomic identities were calculated.

\section{RESULTS}

\section{Detection of GVD in Tunisian vineyards.}

RT-PCR assays successfully amplified the expected 474 bp product from 127 out of 403 tested samples (31.5\%). The highest GVD infection rates were detected in table grapes $(56.5 \%)$ and wine grapes $(20.8 \%)$ collected from commercial vineyards, while a significant lower level of GVD-infection was found in rootstock samples collected from mother plant plots $(12.5 \%)$. The autochthonous vines grown in the collection plots, which were dominantly table grapes, showed a level of GVD-infection of $24.1 \%$.

Among table grapes, the highest infection rates were observed in cvs. Italia and Rich Baba Sam (88.8\%), followed by cv. Dabouki (73.3\%), whereas, among wine grapes, in cvs. Alicante Boushet (25\%), Grenache and Carignan $(21.4 \%)$.

Out of 141 autochthonous vine samples tested, 34 were GVD-positive. Among these vines, significant difference in GVD infection rate was observed in samples coming from north of Tunisia (32.8\%) compared to those collected from the south $(15.5 \%)$. In the rootstocks, GVD was present in $30 \%$ of $1103 \mathrm{P}$ and $11.1 \%$ of $140 \mathrm{Ru}$, while no infection was detected in 110R. 


\section{Genetic diversity analysis.}

The partial CP sequences of 14 Tunisian GVD isolates obtained in this study from different infected Tunisian grapevine accessions (autochthonous, table and wine grape cultivars) were deposited into the European Nucleotide
Archive (ENA) database and assigned accession numbers (Table 1). The sequences were compared with each other and with those of GVD isolates present in the database to obtain more information on the genetic diversity of this virus in Tunisian vineyards.

Table 1. List and identifiers of the coat protein genes of grapevine virus D isolates sequenced and analyzed in this study

\begin{tabular}{c|c|c|c}
\hline Isolate & Cultivar & Origin & Accession number \\
\hline Tn4 & Carignan & Takelsa & LT908458 \\
Tn6 & Dabouki & Takelsa & LT908459 \\
Tn7 & Italia & Essaada & LT908460 \\
Tn8 & Italia & Essaada & LT908461 \\
Tn9 & Marsaoui* & Raf Raf & LT908462 \\
Tn10 & Asli* & Sfax & LT908463 \\
Tn11 & Testouri* & Djebba & LT908464 \\
Tn12 & Dabouki & Takelsa & LT908465 \\
Tn13 & Italia & Takelsa & LT908466 \\
Tn14 & Italia & Takelsa & LT908467 \\
Tn15 & Jerbi* & Degueche & LT908468 \\
TnM1 & Meski & Raf Raf & LT908457 \\
TnG5 & Rich Baba Sam & Bousalem & LT908454 \\
TnI-3 & Italia & Takelsa & LT908455 \\
TnI-5 & Italia & Takelsa & LT908456 \\
\hline
\end{tabular}

* Autochthonous varieties

Sequence analyses showed that the Tunisian isolates share nt identities comprised between $84 \%$ to $99 \%$ (Table 2). Isolates $\operatorname{Tn} 11, \operatorname{Tn} 12, \operatorname{Tn} 13, \operatorname{Tn} 15$ and TnI3 of the same cluster II-a shared $91 \%$ to $96 \%$ nt identities among them, except for the isolate Tn11 that shared $87 \%$ to 92\% identities (Table 2). Isolate $\mathrm{Tn} 4$ of Group II-b showed a high divergence from all the other Tunisian isolates, with nt identities ranging from $87 \%$ to $92 \%$ (Table 2). Isolates $\operatorname{TnG} 5, \operatorname{Tn} 6, \operatorname{Tn} 7, \operatorname{Tn} 8, \operatorname{Tn} 9$, Tn14 and TnI5 of the Group I-a showed $91 \%$ to $100 \%$ of nt identities. The two Tunisian isolates TnM1 and Tn10 of the Group II-c were distant from all other
Tunisian isolates and shared $97 \% \mathrm{nt}$ identity with each other. The clones TnI-3 and TnI- 5 obtained from the same isolate $\mathrm{TnI}$ showed $90 \%$ nt identity between them.

The "intra mean distance" revealed 94\% nt identity for Group II-a, 98\% for Group II-b, $94 \%$ for Group I-b, 95\% for Group I-a and 97\% for Group IIc. The "inter mean distance" between the Groups I and II ranged from $90 \%$ to $91 \%$ at nt level. The sole isolate BM-RM of the Group III showed a great divergence at nt level from the other two groups, with identity values varying between $83 \%$ and 84\% (Tables 3 and 4). 
Table 2. Matrix of nucleotide homologies among the CP sequences of 14 GVD Tunisian isolates

\begin{tabular}{l|c|c|c|c|c|c|c|c|c|c|c|c|c|c|c}
\hline Isolate & TnG5 & TnI3 & TnI5 & TnM1 & Tn4 & Tn6 & Tn7 & Tn8 & Tn9 & Tn10 & Tn11 & Tn12 & Tn13 & Tn14 & Tn15 \\
\hline TnG5 & 100 & & & & & & & & & & & & & & \\
TnI3 & 86 & 100 & & & & & & & & & & & & \\
TnI5 & 93 & 90 & 100 & & & & & & & & & & & \\
TnM1 & 87 & 89 & 91 & 100 & & & & & & & & & & & \\
Tn4 & 88 & 92 & 92 & 91 & 100 & & & & & & & & & & \\
Tn6 & 93 & 90 & 99 & 91 & 92 & 100 & & & & & & & & & \\
Tn7 & 94 & 90 & 98 & 91 & 92 & 99 & 100 & & & & & & & & \\
Tn8 & 91 & 89 & 95 & 87 & 89 & 95 & 95 & 100 & & & & & & & \\
Tn9 & 94 & 90 & 99 & 91 & 92 & 99 & 99 & 96 & 100 & & & & & & \\
Tn10 & 88 & 91 & 91 & 97 & 92 & 91 & 91 & 88 & 91 & 100 & & & & & \\
Tn11 & 84 & 88 & 88 & 87 & 87 & 87 & 87 & 86 & 87 & 87 & 100 & & & \\
Tn12 & 87 & 92 & 92 & 89 & 91 & 92 & 92 & 90 & 92 & 91 & 91 & 100 & & \\
Tn13 & 87 & 91 & 92 & 91 & 92 & 92 & 92 & 90 & 93 & 92 & 92 & 95 & 100 & & \\
Tn14 & 94 & 90 & 99 & 91 & 92 & 99 & 99 & 96 & 100 & 91 & 87 & 92 & 93 & 100 \\
Tn15 & 87 & 91 & 91 & 90 & 90 & 91 & 91 & 90 & 92 & 91 & 91 & 95 & 96 & 92 & 100 \\
\hline
\end{tabular}

Table 3. Intramean distance identity between different subgroups of GVD isolates

\begin{tabular}{|c|c|}
\hline I & $94 \%$ \\
II & $92 \%$ \\
I-a & $95 \%$ \\
I-b & $94 \%$ \\
II-a & $94 \%$ \\
II-c & $97 \%$ \\
II-b & $98 \%$ \\
\hline
\end{tabular}

Table 4. Intermean distance identity between different subgroups of GVD isolates

\begin{tabular}{c|c|c|c|c|c|c}
\hline Subgroup & I-a & I-b & II-a & II-c & II-b & III \\
\hline I-a & $100 \%$ & & & & & \\
I-b & $91 \%$ & $100 \%$ & & & & \\
II-a & $90 \%$ & $91 \%$ & $100 \%$ & & & \\
II-c & $90 \%$ & $90 \%$ & $90 \%$ & $100 \%$ & & \\
II-b & $91 \%$ & $91 \%$ & $91 \%$ & $89 \%$ & $100 \%$ & \\
III & $84 \%$ & $83 \%$ & $83 \%$ & $84 \%$ & $84 \%$ & $100 \%$ \\
\hline
\end{tabular}




\section{Phylogenetic analysis.}

The phylogenetic tree constructed on sequences of the Tunisian and GenBank isolates revealed three groups (GI-III) for GVD, with GI and GII further subdivided into $2(\mathrm{a}, \mathrm{b})$ and 3 subgroups (a-c), respectively (Fig. 1). Most of Tunisian isolates clustered into the Group I (TnG5, Tn6, Tn7, Tn8, Tn9, Tn14 and TnI5) and Group II (Tn11, Tn12, Tn13, Tn15, TnI3, Tn4, TnM1 and Tn10), in particular in the subgroups GI-a and GII-a, together with Italian isolates whose plant material is reported to be originated from Tunisia (Elbeaino et al. 2019). Interesting was the allocation of the Brazilian isolate RM-BR that was highly divergent and distant from all other GVDisolates.
Dissecting the allocations of Tunisian isolates within the phylogenetic tree, isolates from the table cultivars clustered into Group I-a (TnG5, Tn6, Tn7, Tn8, Tn14 and TnI5), II-a (Tn12, Tn13 and TnI3) and II-c (TnM1). In the same three subgroups of isolates clustered all the GVD isolates from autochthonous accessions: Tn9 (Group I-a), Tn11 and Tn15 (Group II-a) and Tn10 (Group II-c). $\mathrm{Tn} 4$ isolate of cv. Carignan was the sole Tunisian isolate to cluster into Group II-b. The two clones TnI3 and TnI5, from the same grapevine sample (TnI), clustered into Group II-a and Group I-a respectively, indicating a putative co-existence of mixture of GVD genetic variants in the same vine sample.

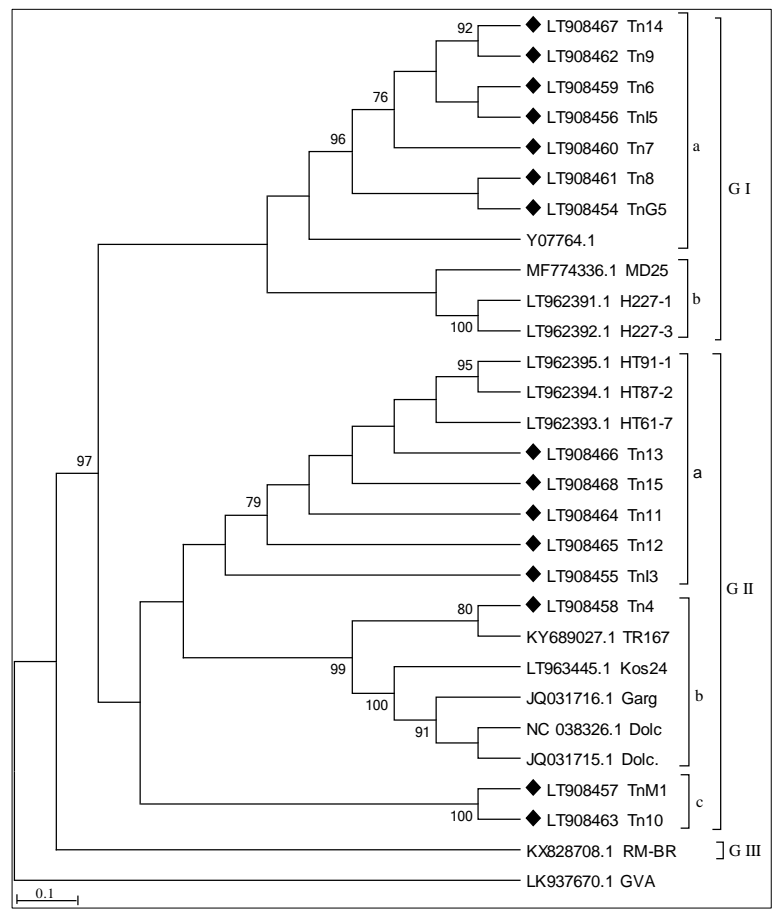

Fig. 1. Phylogenetic tree constructed based on nucleotide sequences of partial CP genes of GVD isolates obtained in this study (indicated with a diamond) and those available in GenBank.The percentage support of bootstrap (>75\%) from 1000 replicates. Accessions numbers are followed by isolates names. G: Group. 


\section{DISCUSSION}

The present study has shown a high prevalence $(31.5 \%)$ of GVD infections in the Tunisian vineyards, a value relatively similar to that of $41.4 \%$ reported in a previous survey (Mahfoudhi et al. 2014).

The high infection rate of GVD, especially in table grapes, together with the high incidence of other viruses in the Tunisian vineyards (Mahfoudhi et al. 1998) reveal an alarming situation for viticulture in the country. GVD is the least studied among all the rugose woodassociated viruses, and its prevalence has only been assessed in a few countries. A similar GVD-infection rate $(31 \%)$ was reported in grapevines from Italy (Boscia et al. 2001), whereas it was significantly lower (9\%) in Turkey (Buzkan et al. 2017).

Despite the natural vector of GVD is still unknown, the high rate of infection by this virus could be due to the presence of a still unidentified vector, especially since the mealybugs, i.e. Planococcus ficus and Planococcus citri known to be involved in the dissemination of other vitiviruses associated with rugose wood disease are very widespread in Tunisia (Mahfoudhi and Dhouibi 2009).

This work provides information on the genetic diversity of GVD in the Tunisian grapevines based on the sequence comparison of a fragment of the $\mathrm{CP}$ gene. In the phylogenetic analysis, the Tunisian isolates clustered into two groups, and in particular in Group II (8 isolates) and
Group I (7 isolates). It is worth noting that most of these isolates were grouped into two subgroups (I-a and II-a), thus suggesting the existence of a large variability among Tunisian GVD-isolates.

The high divergence found between GVD-isolates, based on the sequence analysis of $\mathrm{CP}$ gene, with the presence of six GVD-clusters (considering groups and subgroups), confirms the high genetic diversity of this virus as that reported for other vitiviruses (Elbeaino et al. 2019).

Furthermore, the segregation of Tunisian GVD isolates into different phylogenetic groups regardless of the grapevine plant material type, cultivars, but not the geographical origin as is the case of Tunisian and Italian isolates found close to each other in the phylogenetic tree, suggests that GVD isolates from Tunisia and Italy had a common origin (Elbeaino et al. 2019).

This study extends the knowledge on the incidence of GVD in the Tunisian vineyards and provides the first molecular information on the high sequence variability that could be exploited to develop broad-spectrum molecular diagnostics (RT-PCR) for the detection of different GVD isolates infecting grapevine in nature.

\section{ACKNOWLEDGEMENTS}

This work was financed in part by the Tunisian-Algerian Cooperation, as part of the INNOVITIS project "Valorisation et innovations dans l'utilisation des vignes autochtones nordafricaines".

\section{RESUME}

Selmi I., Elbeaino T., Arezki L., El Air M., Digiaro M. et Mahfoudhi N. 2021. Prévalence et diversité génétique du virus $D$ de la vigne en Tunisie. Tunisian Journal of Plant Protection 16 (2): 19-27.

La prévalence et la diversité génétique des isolats du virus D de la vigne (GVD) provenant de porte-greffes, de cépages de cuve et de variétés de table (introduites et autochtones) cultivés en Tunisie ont été étudiées. Les tests RT-PCR effectués sur le gène de la protéine de la capside 
(CP) ont montré la présence de GVD dans 31,5\% des 403 échantillons testés. Le taux d'infection le plus élevé a été trouvé dans les variétés de table introduites $(56,5 \%)$, suivis par les variétés de table autochtones $(24,1 \%)$, les cépages de cuve $(20,8 \%)$ et les porte-greffes $(12,5 \%)$. Les séquences et les analyses phylogénétiques des gènes partiels du CP de 14 isolats de GVD ont montré des identités nucléotidiques allant de $84 \%$ à $99 \%$. Les isolats tunisiens du GVD ont été groupés en 3 groupes phylogénétiques avec les isolats internationaux inscrits dans le GenBank. La présente étude élargie nos connaissances sur la présence de GVD dans les vignes tunisiennes et sur sa diversité génétique, ce qui est utile pour développer le diagnostic moléculaire à large spectre capables de détecter les différents isolats infectant la vigne.

Mots clés: Vigne, analyses phylogénétiques, RT-PCR, séquences, vitivirus

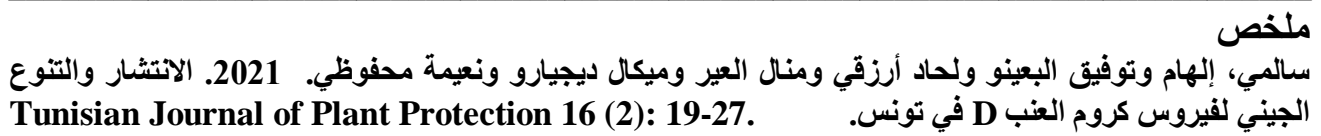

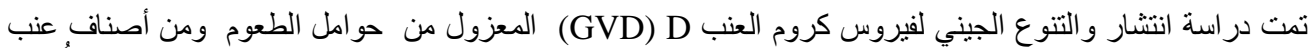

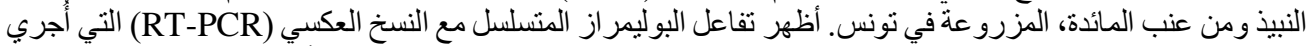

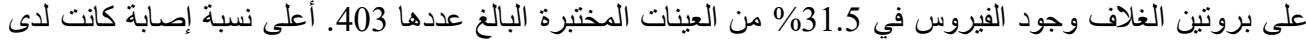

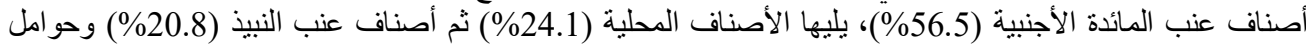

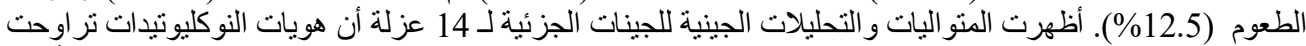

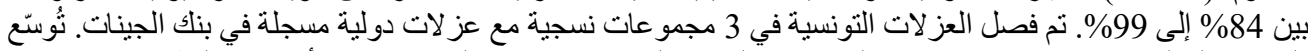

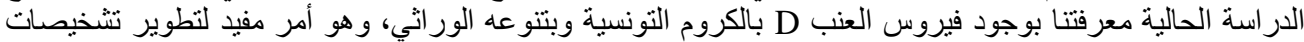

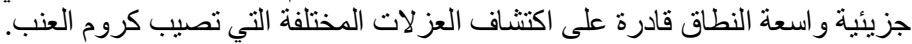

كلمات مفتاحية: تحاليل جينية، تسلسل، كروم العنب، vitivirus ،RT-PCR

\section{LITERATURE CITED}

Abou-Ghanem, N., Saldarelli, P., Minafra, A., Buzkan, N., Castellano, M.A., and Martelli, G.P. 1997. Properties of grapevine virus D, a novel putative Trichovirus. Journal of Plant Pathology 78: 15-25.

Al Rwahnih, M., Sudarshana, M.R., Uyemoto, J.K., and Rowhani, A. 2012. Complete genome sequence of a novel vitivirus isolate from grapevine. Journal of Virology 86 (17): 9545. https://doi.org/ 10.1128/JVI.01444-12

Alabi, O.J., McBride, S., Appel, D.N., Al Rwahnih, M., and Pontasch, F.M. 2019. Grapevine virus $\mathrm{M}$, a novel vitivirus discovered in the American hybrid bunch grape cultivar Blanc du Bois in Texas. Archives of Virology 164: 1739-174. https://doi.org/10.1007/s00705-019-04252-7

Blouin, A.G., Chooi, K.M., Warren, B., Napier, K.R., Barrero, R.A., and MacDiarmid, R.M. 2018 b. Grapevine virus I, a putative new vitivirus detected in coinfection with grapevine virus $\mathrm{G}$ in New Zealand. Archives of Virology 163:
1371-1374. https://doi.org/10.1007/s00705018-3738-5

Blouin, A.G., Keenan, S., Napier, K.R., Barrero, R.A., and MacDiarmid, R.M. 2018a. Identification of a novel vitivirus from grapevines in New Zealand. Archives of Virology 163: 281-284. https://doi.org/10.1007/s00705-017-3581-0.

Bonavia, M., Digiaro, M., Boscia, D., Boari, A., Bottalico, G., and Savino, V. 1996. Studies on "corky rugose wood" of grapevine and on the diagnosis of grapevine virus B. Vitis 35: 53-58.

Boscia, D., Digiaro, M., Safi, M., Garau, R., Zhou, Z., Minafra, A., Abou-Ghanem, N., Sabanadzovic, S., Bottalico, G., and Potere, O. 2001. Production of monoclonal antibodies to Grapevine virus D and contribution to the study of its aetiological role in grapevine disease. Vitis 40: 64-74.

Buzkan, N., Öztırak, M.K., and Balsak, S.C. 2017. First report of Grapevine virus D (GVD) in 
autochthonous grapevine varieties in Turkey. Journal of Plant Pathology99: 803.

Candresse, T., Theil, S., Faure, C., and Marais, A. 2018. Determination of the complete genomic sequence of grapevine virus $\mathrm{H}$, a novel vitivirus infecting grapevine. Archives of Virology 163: 277-280. https://doi.org/10.1007/s00705-017$\underline{3587-7}$

Chevalier, S., Greif, C., Clauzel, J-M., Walter, B., and Fritsch, C. 1995. Use of an immunocapture polymerase chain reaction procedure for the detection of Grapevine virus A in Kober stem grooving infected grapevines. Journal of Phytopathology 143: 369-373

Choueiri, E., Abou-Ghanem, N., and Boscia, D. 1997. Grapevine virus A and Grapevine virus D are serologically distantly related. Vitis 36 : 39 41

Debat, H., Zavallo, D., Brisbane, R.S., Vončina, D., Almeida, R.P.P., Blouin, A.G., Al Rwahnih, M., Gomez-Talquenca, S., and Asurmendi, S. 2019. Grapevine virus L: a novel vitivirus in grapevine. European Journal of Plant Pathology 155: 319-328. https://doi.org/10.1101/314674

Diaz-Lara, A., Golino, D., and Al Rwahnih, M. 2018.Genomic characterization of grapevine virus $\mathrm{J}$, a novel virus identified in grapevine. Archives of Virology 163: 19651967. https://doi.org/10.1007/s00705-0183793-y

Digiaro, M., PopovicBedzrob, M., D’Onghia, A.M., Boscia, D., and Savino, V. 1994. On the correlation between grapevine virus $\mathrm{A}$ and rugose wood. Phytopathologia Mediterranea 33: 187-193.

Elbeaino, T., Chammem, H., Alsaheli, Z., Ben Slimen, A., and Digiaro, M. 2019. Development of RT-PCR assays for the detection and the resultant phylogenetic analysis of four grapevine vitiviruses based on the coat protein sequences. Journal of Virological Methods 113712. https://doi.org/10.1016/j.jviromet.2019.113712

Foissac, X., Svanella-Dumas, L., Gentit, P., Dulucq, M.J., and Candresse, T. 2001. Polyvalent detection of fruit tree Tricho, Capillo and Foveavirus by nested RT-PCR using degenerated and inosine containing primers (DOP RT-PCR). Acta Horticulturae 550: 37 43

Garau, R., Prota, V.A., Piredda, R., Boscia, D., and Prota, U. 1994. On the presence of possible relationship between Kober stem grooving and Grapevine virus A. Vitis 33: 161-163.

Kumar, S., Stecher, G., and Tamura, K. 2016. MEGA7: Molecular evolutionary genetics analysis version 7.0 for bigger datasets. Molecular Biological Evolutionary 33: 18701874. https://doi.org/10.1093/molbev/msw054

Mahfoudhi, N., and Dhouibi, M.H. 2009. Survey of mealybugs (Hemiptera: Pseudococcidae) and their natural enemies in Tunisian vineyards. African Entomology17: 154-160. https://doi.org/10.4001/003.017.0205

Mahfoudhi, N., Digiaro, M., Savino, V., and Di Terlizzi, B. 1998. Viruses and virus diseases of grapevine in Tunisia. EPPO Bulletin 28: $197-$ 204.

Mahfoudhi, N., Soltani, I., El Air, M., Digiaro, M., and Elbeaino, T. 2014. Occurrence and widespread distribution of Grapevine virus D in Tunisian grapevines. Journal of Plant Pathology 96 (2): 431. http://dx.doi.org/10.4454/JPP.V96I2.001

Martelli, G.P. 2014. Directory of virus and virus-like diseases of the grapevine and their agents. Journal of Plant Pathology 96: 1-136

Martelli, G.P., and Boudon-Padieu, E. 2006 Directory of infectious diseases of grapevine and viroses and virus-like diseases of the grapevine: Bibliographic report 1998-2004. Options Méditerranéennes Serie B, N55, 279.

Nakaune, R., Toda, S., Mochizukki, M., Nakano, M. 2008. Identification and characterization of a new vitivirus from grapevine. Archives of Virology 153: 1827-1832. https://doi.org/10.1007/s00705-008-0188-5

Rowhani, A., Daubert, S., Arnold, K., Al Rwahnih, M., Klaassen, V., Golino, D., and Uyemoto, J.K. 2018. Synergy between grapevine vitiviruses and grapevine leafroll viruses. European Journal of Plant Pathology 4: 919 925. https://doi.org/10.1007/s10658-018-1426$\underline{7}$ 
